\title{
Variable Nuclear Localization of $\alpha$-Catenin in Colorectal Carcinoma
}

\author{
Mona El-Bahrawy, lan Talbot, Richard Poulsom, and Malcolm Alison \\ Histopathology Department (ME-B, MA), Hammersmith Hospital, Faculty of Medicine, Imperial College of Science, \\ Technology and Medicine; and Colorectal Cancer Unit (IT), Imperial Cancer Research Fund, St. Marks Hospital and \\ Histopathology Unit (RP), Imperial Cancer Research Fund, Lincoln's Inn Fields, London, United Kingdom
}

SUMMARY: The E-cadherin/catenin complex plays a major role in epithelial cell-cell adhesion. Both $\beta$-catenin and $\gamma$-catenin bind directly to the cytoplasmic domain of E-cadherin whereas $\alpha$-catenin links the bound $\beta$-catenin or $\gamma$-catenin to the actin microfilament network of the cellular cytoskeleton. Significant changes in the expression and/or structure of members of the complex can occur in neoplasia. Several studies have reported on the nuclear localization of $\beta$ - and $\gamma$-catenin and on their role in influencing the transcriptional activity of several proto-oncogenes. The cellular localization of $\alpha$-catenin has not been studied in detail. The aim of this study was to investigate the cellular localization of $\alpha$-catenin in colorectal carcinoma both in vitro and in vivo and to assess whether it might be relevant to tumor behavior. The expression of $\alpha$-catenin was examined in a panel of colorectal carcinoma cell lines (SW480, SW620, HCT116, HT29, and Caco-2) using a combination of immunohistochemistry, confocal fluorescence microscopy, and Western blotting. The expression of $\alpha$-catenin was also studied by immunohistochemistry in 15 sporadic colorectal adenomas, 30 sporadic colorectal adenocarcinomas, and their 13 lymph node metastases. From familial adenomatous polyposis patients, 20 adenomas and 5 adenocarcinomas were studied. Nuclear localization of $\alpha$-catenin was detected in the colorectal carcinoma cell lines when the cells were dispersed rather than confluent. $\alpha$-catenin was not detected in the nuclei in any of the sporadic or familial adenomas. However, it was detected in one sporadic and one familial adenocarcinoma but not in any of the lymph node deposits. $\alpha$-catenin can localize to the nuclei of colorectal tumor cells, and this may be related to lack of perception of connection to adjacent cells. (Lab Invest 2002, 82:1167-1174).

$A$ dhesion between epithelial cells is mediated mainly by $\mathrm{E}$-cadherin, localized largely in the adherens junctions. The extracellular domain of an E-cadherin molecule interacts with that of another E-cadherin molecule of the neighboring cell in the presence of calcium ions to form strong cell-cell adhesion (Duband et al, 1987; Takeichi, 1990). The cytoplasmic domain of $\mathrm{E}$-cadherin is associated with a group of closely related but distinct proteins termed catenins (Gumbiner and McCrea, 1993; Takeichi, 1991). E-cadherin binds to $\beta$-catenin or $\gamma$-catenin. $\alpha$-catenin also binds either to $\beta$-catenin or $\gamma$-catenin with the result that complexes of either E-cadherin $/ \beta$ catenin $/ \alpha$-catenin or E-cadherin $/ \gamma$-catenin $/ \alpha$-catenin are formed (Hinck et al, 1994). $\beta$-catenin and $\gamma$-catenin compete for the same region of $\alpha$-catenin: $\beta$-catenin binds to $\alpha$-catenin with higher affinity than does $\gamma$-catenin (Obama and Ozawa, 1997). $\alpha$-catenin forms a particularly important link in cell-cell adhesion because it mediates the interaction between the cadherin/catenin complex and the actin cytoskeleton through its associations with $\alpha$-actinin and actin fila-

\section{DOI: 10.1097/01.LAB.0000028821.41246.6A}

Received March 6, 2002.

Mona El-Bahrawy is supported by an Egyptian Government scholarship. Address reprint requests to: Dr. M. Alison, Histopathology Department, Hammersmith Hospital, DuCane Road, London W12 ONN, United Kingdom.E-mail:m.alison@ic.ac.uk ments (Knudsen et al, 1995; Nieset et al, 1997). This binding is essential for the adhesive function of E-cadherin and for establishment of tight physical cell-cell adhesion (Nagafuchi and Takeichi, 1988; Nathke et al, 1994; Ozawa et al, 1990; Tsukita et al, 1992; Wachsstock et al, 1987). Any significant change in expression, structure, or function of any one of the components of the E-cadherin/catenin complex can lead to adherens junction disassembly: such changes are implicated in loss of tumor differentiation and in the development of an invasive tumor phenotype (Smith and Pignatelli, 1997).

The expression of $\alpha$-catenin is often reduced during tumor progression (Hirohashi, 1998). Mutations in the $\alpha$-catenin gene or lack of its expression have been reported in several cancer cell lines. A human ovarian carcinoma-derived cell line (Ov2008) expresses a mutant form of the $\alpha$-catenin protein lacking the extreme $\mathrm{N}$ terminus of the wild-type protein. The altered form of $\alpha$-catenin expressed in Ov2008 cells fails to bind efficiently to $\beta$-catenin and is localized in the cytoplasm. The lung carcinoma cell line PC9 does not express $\alpha$-catenin (Bullions et al, 1997; Watabe et al, 1994). Reintroduction of $\alpha$-catenin into such cell lines reduces cell growth and attenuates tumor formation.

Cells of the lung carcinoma line PC9 do not express $\alpha$-catenin but do express E-cadherin and $\beta$-catenin; they grow singly in suspension and cannot aggregate (Hirano et al, 1992; Shimoyama et al, 1992). Transfection of PC9 cells with $\alpha$-catenin cDNA activates 
cadherin-mediated cell-cell associations (Hirano et al, 1992). Stable expression of $\alpha$-catenin cDNA in a poorly differentiated colorectal carcinoma cell line lacking $\alpha$-catenin resulted in a 5 -fold increase in the level of $\mathrm{Ca}^{2+}$-dependent cell-cell aggregation (Breen et al, 1993). Thus, $\alpha$-catenin is indispensable for cadherin function.

Until now, consideration of $\alpha$-catenin has focused on its overall level of expression and its redistribution to the cytoplasm as shown by immunocytochemistry. In this study, we investigated the expression of $\alpha$-catenin both in vivo and in vitro and have shown that there is up-regulation of $\alpha$-catenin in colorectal neoplasms. We report that $\alpha$-catenin, like $\beta$-catenin, shuttles between the cytoplasm and the nucleus with changes in cell shape and cell-cell contact. We also report for the first time the nuclear localization of $\alpha$-catenin in a small percentage of colorectal adenocarcinomas as well as in various transformed cell lines.

\section{Results}

\section{Immunocytochemical Detection of $\alpha$-Catenin in Cell Lines}

In the cell line SW480, which grows mostly as noncohesive cell clusters, there was no membranous localization of $\alpha$-catenin, but there was cytoplasmic expression and evident nuclear localization (Fig. 1). This pattern was also observed in SW620, a cell line derived from a lymph node metastasis, from the same patient as SW480. However, the level of $\alpha$-catenin expression was generally weaker in SW620 as compared with SW480. In confluent monolayers of HCT 116, HT29, and Caco-2, there was very evident membranous staining at sites of cell-cell contact, weak cytoplasmic staining, and no nuclear localization. However, when dispersed cells were examined in the preconfluent state, cytoplasmic expression was evidently increased with perinuclear accentuation and nuclear immunoreactivity (Fig. 1, insets).

\section{Confocal Immunofluorescence Microscopy}

In all cell lines, cells grown at very low density and without cell-cell contacts showed cytoplasmic staining and punctate nuclear staining for $\alpha$-catenin (Fig. $2 \mathrm{~A})$. In the confluent monolayers of HCT116, HT29, and Caco-2, there was strong membranous localization but no nuclear staining (Fig. 2A). To confirm the nuclear localization of $\alpha$-catenin, cells were examined at different levels and from different angles (Fig. 2B and $\mathrm{C})$.

\section{Immunohistochemical Detection of $\alpha$-Catenin in Human Tumors}

All the adenomas from patients with familial adenomatous polyposis (FAP) showed preservation of membranous localization and increased cytoplasmic expression compared with the adjacent non-neoplastic mucosa. In the sporadic adenomas, membranous localization was preserved in all but one severely dysplastic tubular adenoma, which showed decreased membranous staining for $\alpha$-catenin. Increased cytoplasmic expression was observed in 13 of 15 adenomas.

All carcinomas from patients with FAP showed increased cytoplasmic accumulation of $\alpha$-catenin in comparison with the adjacent non-neoplastic mucosa. Membranous localization of the proteins was preserved in four of the adenocarcinomas, whereas in one (a poorly differentiated adenocarcinoma), there was heterogeneity in the membranous staining of $\alpha$-catenin, being weak to normal in some areas and absent in other areas where there was obvious nuclear localization of $\alpha$-catenin in almost all tumor cells (Fig. $3 A)$.

In sporadic adenocarcinomas, compared with the non-neoplastic adjacent mucosa, there was decreased membranous localization in 12 of 30 (40\%) carcinomas and increased cytoplasmic expression of $\alpha$-catenin in all but 3 carcinomas $(27 / 30,90 \%)$. One moderately differentiated adenocarcinoma showed nuclear localization of $\alpha$-catenin in some areas of the tumor (Fig. 3B-D). In nearly all the cells showing nuclear $\alpha$-catenin, there was complete loss of membranous expression. In other areas where the cells showed strong membranous staining, no nuclear localization was observed. At the margins of the tumor, the cells at the invasive front showed complete loss of membranous staining and strong nuclear $\alpha$-catenin localization (Fig. 3D). Table 1 summarizes the results of $\alpha$-catenin expression in the tumors. All lymph node deposits showed membranous and cytoplasmic localization, but no nuclear localization was observed in any of the metastatic deposits (data not shown).

\section{Discussion}

An essential role for $\alpha$-catenin in cadherin-dependent adhesion has been demonstrated in cell culture (Hirano et al, 1992; Nagafuchi et al, 1994). For several human cancer cell lines, such as the human lung cancer cell line (PC9) (Shimoyama et al, 1992), the prostate adenocarcinoma cell line (PC3) (Ewing et al, 1995; Morton et al, 1993), and several human esophageal tumors (Kadowaki et al, 1994), it was shown that $\alpha$-catenin suppresses an invasive phenotype by restoring E-cadherin dependent adhesion (Ewing et al, 1995).

$\alpha$-catenin may influence invasion and metastasis. Immunohistochemical analysis showed that many colorectal carcinomas have reduced expression of either E-cadherin (29\%) or $\alpha$-catenin (56\%), but increased tumor cell invasion and metastasis correlated with reduced expression of $\alpha$-catenin (Gofuku et al, 1999).

In our present study, none of the adenomas or carcinomas (sporadic and familial) showed downregulation of $\alpha$-catenin. On the contrary, there was an actual increase in cytoplasmic expression of the protein, with no correlation with the type, size, degree of 

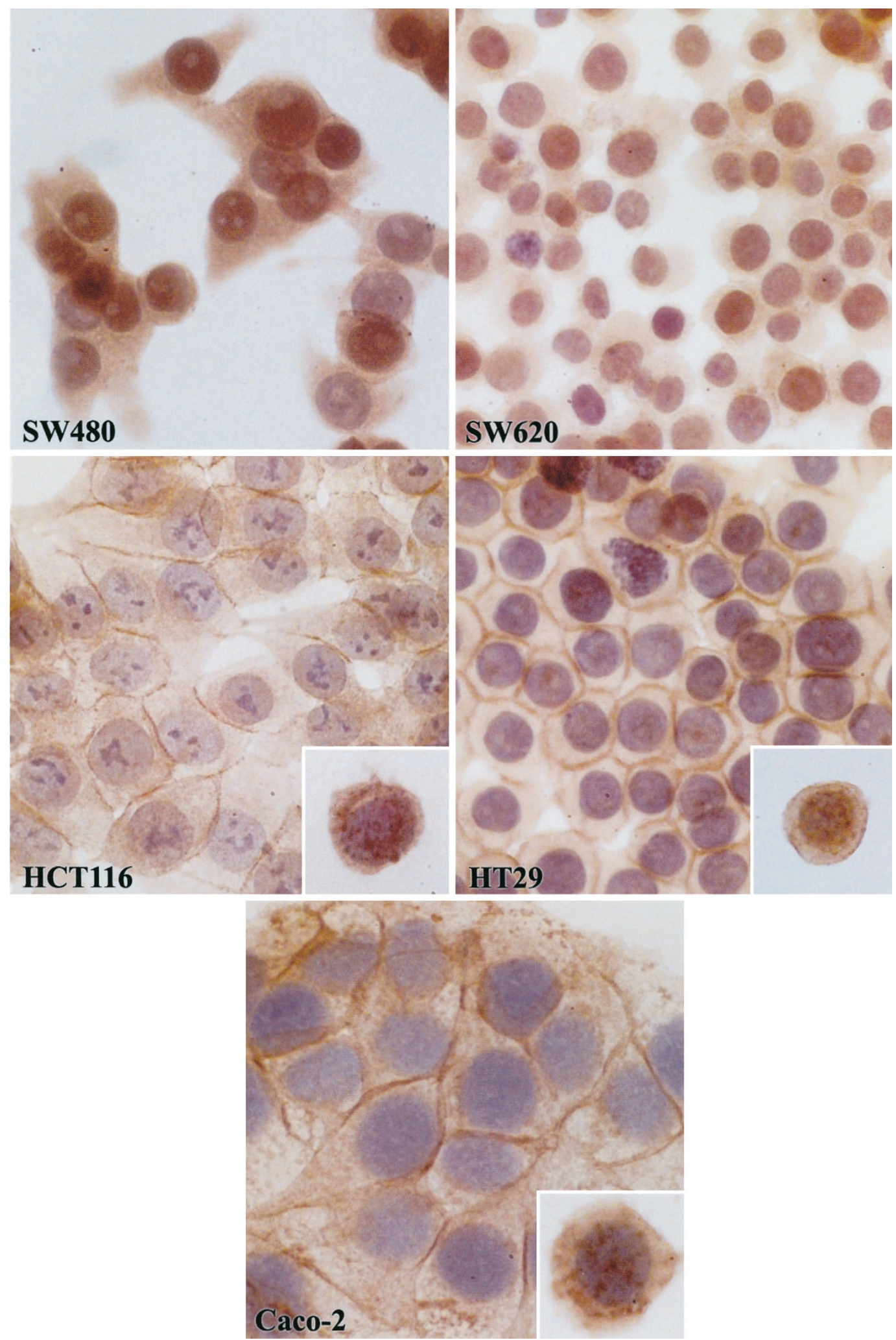

\section{Figure 1.}

Immunocytochemical detection of $\alpha$-catenin in a panel of colorectal carcinoma cell lines.

dysplasia in adenomas, or the grade or stage of carcinomas.

We also report the nuclear localization of $\alpha$-catenin in a panel of colorectal carcinoma cell lines, which was evident only when the cells were dispersed rather than confluent. Although we were concerned initially that the nuclear localization of $\alpha$-catenin observed by immunohistochemical analysis might be an artifact of 
A
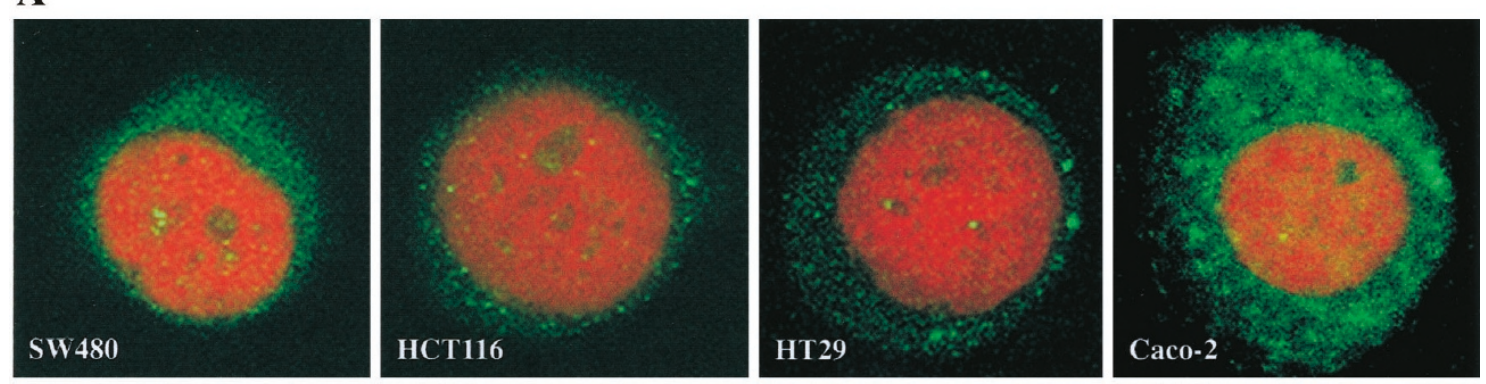

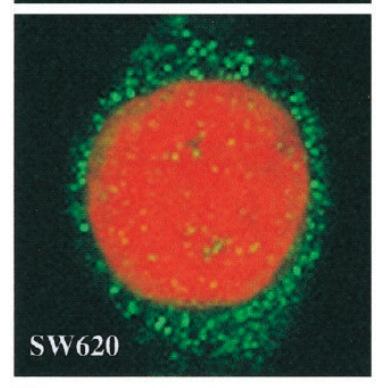

B

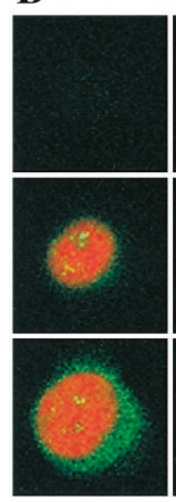

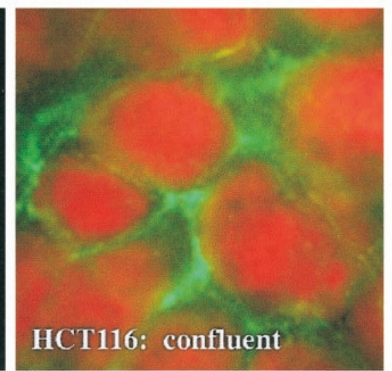

HCT116: confluent

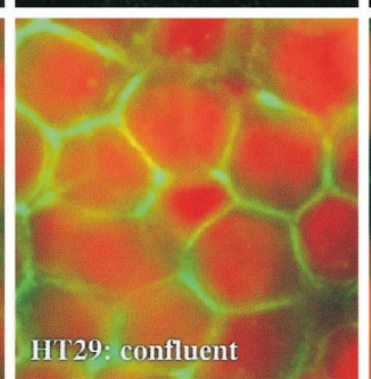

C

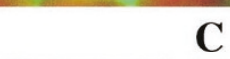

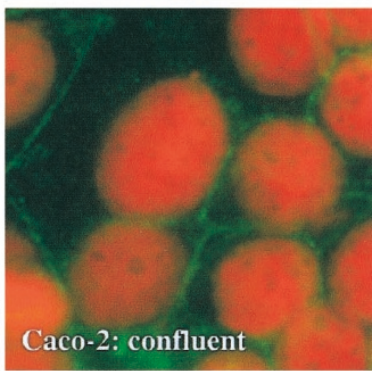

Caco-2: confluent

Figure 2.

Immunocytochemical detection of $\alpha$-catenin in colorectal adenocarcinoma cell lines studied by confocal fluorescence microscopy. The nuclei appear red, being stained by propidium iodide, whereas $\alpha$-catenin immunoexpression appears green, being stained by FITC (fluorescein isothiocyanate)-labeled antibody. A, Dispersed cells of the cell lines SW480, SW620, HCT116, HT29, and Caco-2 show cytoplasmic expression of $\alpha$-catenin and punctate nuclear staining with larger puncta focally. In confluent monolayers of HCT116, HT29, and Caco-2, $\alpha$-catenin is mainly localized in the cell membranes, and no nuclear staining is seen. B, A gallery of images taken at different levels of a cell from the cell line SW480 shows diffuse $\alpha$-catenin localization in the cytoplasm and the nucleoplasm. There are focal areas of concentration of $\alpha$-catenin in the nucleus. C, Side views show the level in the nucleus at which the image is taken, confirming that it is through the nucleus.

the fixation procedures or that the protein is only perinuclear, examination of the cells by the confocal microscope confirmed the nuclear localization of $\alpha$-catenin.

We performed Western blot analysis of protein extracts from the five cell lines, using the same anti$\alpha$-catenin monoclonal antibody used for the immunohistochemical studies, to confirm the specificity of the antibody and to ensure that it was not cross-reacting with a homologous nuclear protein. A single band of approximately $103 \mathrm{kd}$, corresponding to intact $\alpha$-catenin was seen (data not shown).

There did not seem to be a correlation between the presence of mutations in the adenomatous polyposis coli (APC) protein and/or $\beta$-catenin and the nuclear localization of $\alpha$-catenin. $A P C$ and $\beta$-catenin status of the cell lines we used are well characterized. SW480, SW620, and HT29 have APC gene mutations, HCT116 has a $\beta$-catenin gene mutation, and Caco-2 has $A P C$ and $\beta$-catenin gene mutations (llyas et al, 1997). However, our study shows that it is actually cell-cell contact that influences the cellular distribution of $\alpha$-catenin, contact being seemingly crucial for the recruitment of the protein to the cell membrane. One possibility is that $\alpha$-catenin responds to changes in the actin cytoskeleton. $\alpha$-catenin associates with a number of cytoskeletal proteins including $\alpha$-actinin, vinculin, and actin (Provost and Rimm, 1999). Such interactions may regulate the ability of endogenous $\alpha$-catenin to enter the nucleus and control transcription. $\alpha$-catenin was only evident in the nucleus when cells were dispersed and not when they formed confluent monolayers, which may explain why nuclear localization of $\alpha$-catenin is not readily detectable in tumors where the cells usually grow as 

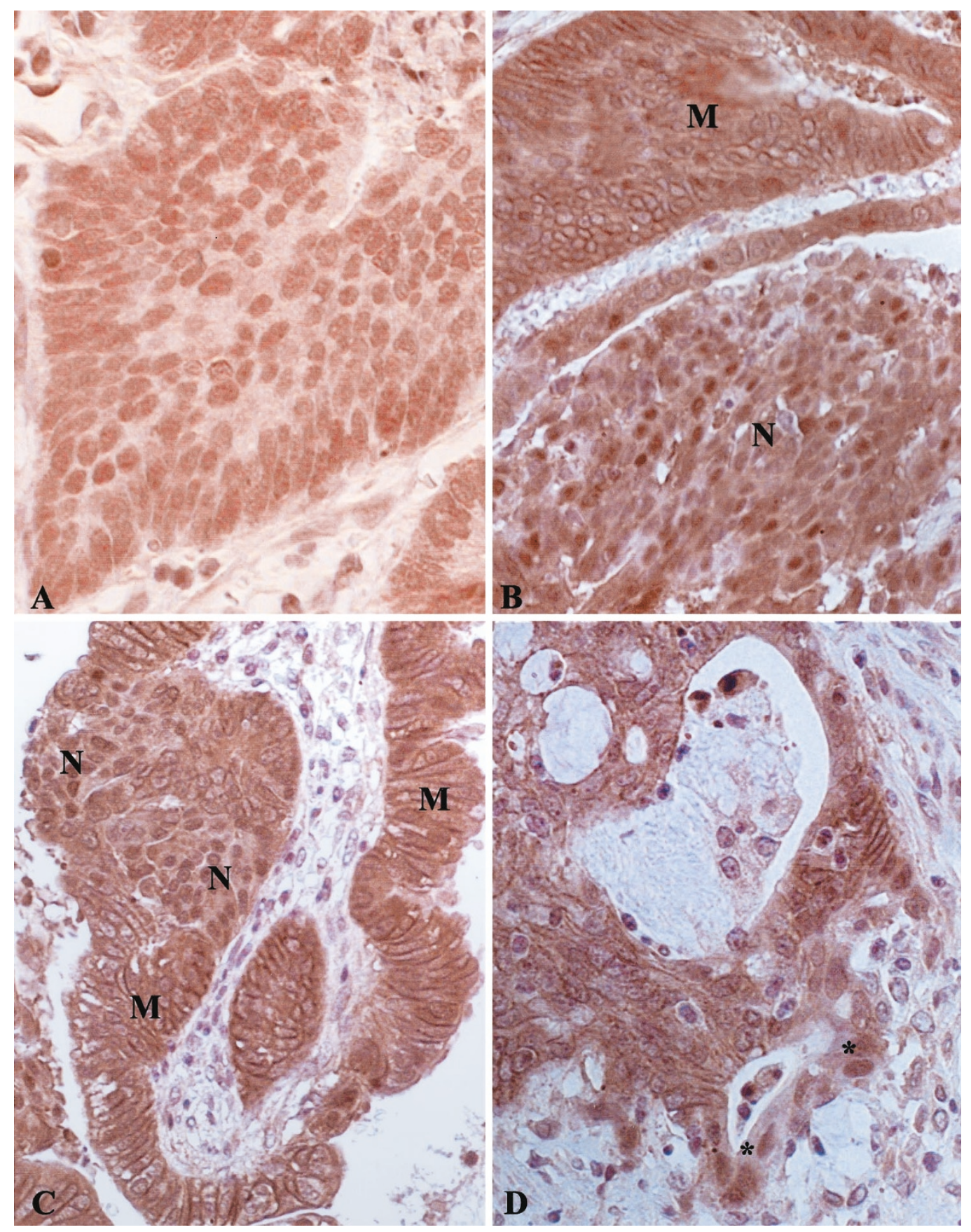

Figure 3.

Immunohistochemical detection of $\alpha$-catenin in two colorectal adenocarcinomas. A, In a poorly differentiated colorectal adenocarcinoma from a patient with familial adenomatous polyposis (FAP), all cells in this field show nuclear localization of $\alpha$-catenin with loss of membranous staining. B, In a moderately differentiated sporadic colorectal adenocarcinoma, there were large areas where cells showed cytoplasmic and nuclear immunostaining for $\alpha$-catenin with loss of membranous localization (M). Other areas showed preserved membranous staining and no nuclear localization (M). C, In the same case, the two patterns were observed within individual projections with areas exhibiting nuclear localization sharply demarcated $\left(M\right.$. D, At the margin, the cells at the invasive front ( ${ }^{*}$ ) showed loss of membranous staining but strong nuclear expression of $\alpha$-catenin.

epithelial sheets. It is likely that, in such a state, nuclear $\alpha$-catenin is below the level detectable by immunohistochemistry.

In our present study, we found obvious nuclear localization of $\alpha$-catenin in two colorectal adenocarcinomas. Consistent with our in vitro observations, in the cells showing nuclear localization of $\alpha$-catenin, there was more or less complete loss of membranous staining. The nuclear localization of $\alpha$-catenin in these tumors may be caused by failure of nuclear export due to an $\alpha$-catenin mutation or a failure in a nuclearcytoplasmic shuttling system for $\alpha$-catenin. There does not seem to be a correlation between nuclear localization of $\alpha$-catenin and that of $\beta$-catenin, as $\beta$-catenin nuclear localization was seen in the majority of the studied tumors, which did not show $\alpha$-catenin 
Table 1. Expression of $\alpha$-Catenin in Familial and Sporadic Colorectal Neoplams as Compared with the Adjacent Non-Neoplastic Mucosa

\begin{tabular}{|c|c|c|c|c|c|c|}
\hline \multirow[b]{2}{*}{ Tumors } & \multicolumn{2}{|c|}{ Membrane } & \multicolumn{2}{|c|}{ Cytoplasm } & \multicolumn{2}{|c|}{ Nucleus } \\
\hline & Preserved & Decreased & Normal & Increased & Absent & Present \\
\hline Adenomas from FAP patients & 20/20 & $0 / 20$ & $0 / 20$ & 20/20 & $20 / 20$ & $0 / 20$ \\
\hline Sporadic adenomas & $14 / 15$ & $1 / 15$ & 2/15 & $13 / 15$ & $15 / 15$ & $0 / 15$ \\
\hline Carcinomas from FAP patients & $4 / 5$ & $1 / 5$ & $0 / 5$ & $5 / 5$ & $4 / 5$ & $1 / 5$ \\
\hline Sporadic carcinomas & $18 / 30$ & $12 / 30$ & $3 / 30$ & $27 / 30$ & $29 / 30$ & $1 / 30$ \\
\hline
\end{tabular}

FAP, familial adenomatous polyposis.

nuclear staining (data not shown). This argues against the possibility of $\alpha$-catenin localizing in the nucleus as a passive partner of nuclear $\beta$-catenin. It is possible that $\alpha$-catenin, when present in the nucleus, also has consequences for gene expression different from those affected by $\beta$-catenin.

Giannini et al (2000) examined $\beta$-catenin signaling in colon cancer cell lines and found that loss of $\alpha$-catenin expression correlated with increased $\beta$-catenin-T cell factor (TCF)-dependent transcription. The mechanism by which $\alpha$-catenin inhibits $\beta$-catenin-TCF-dependent transcription has been proposed to be sequestration of $\beta$-catenin in the cytoplasm and is generally believed to result from its promotion of cell-cell adhesion (Simcha et al, 1998). Ectopic expression of $\alpha$-catenin in the nucleus inhibited $\beta$-catenin-TCF signaling. Transfection with $\alpha$-catenin targeted to the nucleus inhibits transcription activity to the same extent as nontargeted $\alpha$-catenin. Because $\alpha$-catenin associated stably with the $\beta$-catenin-TCF complex, it was proposed that $\alpha$-catenin may inhibit $\beta$-catenin-TCF transcription either by preventing DNA binding or by altering the $\beta$-catenin-TCF interactions with other proteins that regulate transcription in vivo (Giannini et al, 2000). Factors that regulate nuclear entry of $\alpha$-catenin would link signaling events in the cytoplasm to $\beta$-catenin-dependent transcription in the nucleus.

Giannini et al (2000), using immunofluorescence and confocal microscopy, reported nuclear localization of $\alpha$-catenin in the cell line SW480 but not in HCT 116. However, in that study, confluent monolayers of HCT116 were examined, whereas the present study found $\alpha$-catenin nuclear localization only in dispersed cells. Moreover, they transfected the cells with green fluorescent protein-tagged $\alpha$-catenin, which was detected both in the cytoplasm and the nuclei of the cells, confirming the ability of $\alpha$-catenin to translocate to the nucleus. The present study is the first report of the nuclear localization of $\alpha$-catenin in a panel of colorectal carcinoma cell lines as well as in a small proportion of colorectal adenocarcinomas. Our study shows that a relative lack of cell-cell contacts appears instrumental in this nuclear localization.

\section{Materials and Methods}

\section{Cell Lines}

Five human colorectal adenocarcinoma cell lines were investigated. The cell lines SW480, SW620, HT29,
HCT116, and Caco-2 were obtained from the American Type Culture Collection (ATCC).

\section{Human Tissue}

Formalin fixed paraffin embedded material from coIonic resection specimens and polypectomy specimens were obtained from the archived material of the Department of Histopathology, Hammersmith Hospital, London, United Kingdom. The samples comprised 30 cases with sporadic colorectal adenocarcinomas (13 with lymph node metastases) and 15 cases with sporadic adenomas. Formalin fixed paraffin embedded material from colonic resection specimens of five FAP patients who had developed colorectal adenocarcinomas were obtained from the archived material of the Academic Department of Pathology, St. Mark's Hospital, London, United Kingdom. The samples comprised 20 adenomas and 5 adenocarcinomas.

Adenomas were graded and classified according to histological type and degree of dysplasia (Jass and Sobin, 1989), and carcinomas were graded as either well, moderate, or poorly differentiated (Jass and Sobin, 1989) and staged according to Dukes' staging system (Dukes, 1932).

The sporadic adenomas comprised 7 tubular adenomas (4 moderately dysplastic and 3 severely dysplastic), and 8 tubulovillous adenomas (7 moderately dysplastic and 1 severely dysplastic). The sporadic carcinomas comprised 1 well differentiated adenocarcinoma (Dukes' A), 24 moderately differentiated adenocarcinomas (2 Dukes' A, 12 Dukes' B, 10 Dukes' C), and 5 poorly differentiated adenocarcinomas (2 Dukes' B, 3 Dukes' C).

The neoplasms from five FAP patients comprised 20 adenomas, 15 tubular adenomas (moderately dysplastic), 5 tubulovillous adenomas (2 mildly dysplastic, 3 moderately dysplastic), and 2 villous adenomas (moderately dysplastic). The carcinomas comprised 1 well differentiated (Dukes' A), 2 moderately differentiated (Dukes' A and Dukes' B), and 2 poorly differentiated adenocarcinomas (Dukes' B, and Dukes' C).

\section{Antibodies}

Anti- $\alpha$-catenin antibody (Transduction Laboratories, Lexington, Kentucky, catalogue number: C21620) was used for immunohistochemistry. Biotinylated goat antimouse immunoglobulin (lg), fluorescein isothiocyanate (FITC) conjugated rabbit antimouse lg (Dako Ltd., 
Cambridge, United Kingdom) were used as secondary antibodies for immunohistochemistry and immunofluorescence, respectively.

\section{Immunohistochemical Analysis of Tissue Sections}

Immunohistochemistry was performed using the streptavidin-biotin complex indirect immunoperoxidase method. Sections were dewaxed, rehydrated, and incubated with $0.3 \%$ hydrogen peroxide $\left(\mathrm{H}_{2} \mathrm{O}_{2}\right)$ for 30 minutes to block endogenous peroxidase activity. Antigen retrieval was performed by microwaving for 20 minutes in $0.01 \mathrm{M}$ citrate buffer $(\mathrm{pH} \mathrm{6.0)}$ at 750 W. After rinsing in PBS, background staining was blocked using normal goat serum (1:20; Dako Ltd.) for 10 minutes. The sections were incubated with the primary antibody overnight at $4^{\circ} \mathrm{C}$. The anti- $\alpha$-catenin was used at a concentration of $4 \mu \mathrm{g} / \mathrm{ml}$. After washing with PBS, the sections were then incubated with biotinylated goat antimouse Ig (Dako Ltd.) for 30 minutes, washed with PBS, then incubated with a streptavidin-peroxidase complex (1: 500; Amersham Pharmacia Biotech, Bucks, United Kingdom) for 30 minutes. The sections were developed with activated 3,3'-diaminobenzidine-tetrahydrochloride solution (Sigma-Aldrich, Dorset, United Kingdom) and 0.1\% $\mathrm{H}_{2} \mathrm{O}_{2}$ and counterstained with hematoxylin.

For negative controls, duplicate sections were used in which the primary antibodies were omitted and replaced with PBS. Non-neoplastic colonic mucosa present in the histological sections was used as an internal control.

Sections were examined by light microscopy, and staining was assessed with respect to localization of staining (membranous, cytoplasmic, and nuiclear) and intensity of staining relative to the adjacent mucosa. Distinct membranous and weak cytoplasmic staining were considered normal. Weak or absent membranous staining, intense cytoplasmic, and nuclear staining were considered abnormal.

\section{Immunocytochemical Study of Cell Lines}

Cells were grown on tissue culture multispot glass microscope slides (Hendley, Loughton, Essex, United Kingdom), in a $37^{\circ} \mathrm{C}$ and $10 \% \mathrm{CO}_{2}$ incubator. Cells were grown to different levels of subconfluence and confluence. The slides were washed for 5 minutes in cold PBS. The cells were fixed in acetone/methanol (1:1) for 10 minutes at $-20^{\circ} \mathrm{C}$. The slides were allowed to air dry completely. Endogenous peroxidase was blocked by incubating the slides in $0.3 \% \mathrm{H}_{2} \mathrm{O}_{2}$ in PBS for 15 minutes. The slides were incubated in normal goat serum (1/20; Dako Ltd.) for 15 minutes to block nonspecific binding. Primary antibody was then added to the cells ( $\alpha$-catenin: 1:250), and the slides were incubated overnight at $4^{\circ} \mathrm{C}$. Primary antibody was added to 3 wells and, for the fourth well-used as a negative control-only PBS was added. The cells were washed in PBS and then sequentially incubated with secondary antibody, streptavidin-peroxidase complex, developed and mounted as above.
The slides were examined using a conventional light microscope and the level of expression and cellular distribution of the proteins between membrane, cytoplasm, and nucleus assessed.

\section{Immunofluorescence and Confocal Microscopy}

Cells were grown and fixed as above. The slides were incubated in normal rabbit serum (1: 20; Dako Ltd.) for 1 hour to block nonspecific binding. Primary antibody was then added to the cells ( $\alpha$-catenin: 1: 250). RNAase (Boehringer Mannheim, Mannheim, Germany) was added to the primary antibody to a final concentration of $100 \mu \mathrm{g} / \mathrm{ml}$ to lyse cellular ribonucleic acids present in the cytoplasm and in the nucleus (the largest amount of nuclear RNA is in the nucleolus). The slides were incubated overnight at $4^{\circ} \mathrm{C}$, washed in PBS, and then secondary antibody (FITC conjugated rabbit antimouse Ig, 1:250; Dako Ltd.) was added to each well. The slides were incubated in the dark for 45 minutes at room temperature, then washed in PBS, and mounted using mounting medium containing propidium iodide (Vectashield mounting medium; Vector Laboratories, Inc., Burlingame, California). The slides were examined using the confocal microscope. The cells were examined on a Zeiss Axioplan 2 microscope, using a $\times 63$ oil immersion lens (Numerical aperture 1.4), $488 \mathrm{~nm}$ argon laser, and $543 \mathrm{~nm}$ helium neon laser. The software Zeiss LSM 510 system was used for acquisition and analysis of data. A series of optical sectioning images were taken through the cells at 0.2 to $0.4 \mu \mathrm{m}$ intervals. The images were examined to assess the localization of the staining.

\section{References}

Breen E, Clarke A, Steele G Jr, and Mercurio AM (1993). Poorly differentiated colon carcinoma cell lines deficient in alpha-catenin expression express high levels of surface $\mathrm{E}$-cadherin but lack $\mathrm{Ca}(2+)$-dependent cell-cell adhesion. Cell Adhes Commun 1:239-250.

Bullions LC, Notterman DA, Chung LS, and Levine AJ (1997). Expression of wild-type alpha-catenin protein in cells with a mutant alpha-catenin gene restores both growth regulation and tumor suppressor activities. Mol Cell Biol 17:4501-4508.

Duband JL, Dufour S, Hatta K, Takeichi M, Edelman GM, and Thiery JP (1987). Adhesion molecules during somatogenesis in the avian embryo. J Cell Biol 104:1361-1374.

Dukes CE (1932). The classification of cancer of the rectum. J Pathol Bacteriol 35:323-332.

Ewing CM, Ru N, Morton RA, Robinson JC, Wheelock MJ, Johnson KR, Barrett JC, and Isaacs WB (1995). Chromosome 5 suppresses tumorigenicity of PC3 prostate cancer cells: Correlation with re-expression of alpha-catenin and restoration of E-cadherin function. Cancer Res 55:48134817.

Giannini AL, Vivanco M, and Kypta RM (2000). Alpha-catenin inhibits beta-catenin signaling by preventing formation of a beta-catenin.T-cell factor.DNA complex. J Biol Chem 275: 21883-21888.

Gofuku, J, Shiozaki H, Tsujinaka T, Inoue M, Tamura S, Doki Y, Matsui S, Tsukita S, Kikkawa N, and Monden M (1999). 
Expression of E-cadherin and alpha-catenin in patients with colorectal carcinoma. Correlation with cancer invasion and metastasis. Am J Clin Pathol 111:29-37.

Gumbiner BM and McCrea PD (1993). Catenins as mediators of the cytoplasmic functions of cadherins. J Cell Sci 17:155158.

Hinck L, Nathke IS, Papkoff J, and Nelson WJ (1994). Dynamics of cadherin/catenin complex formation: Novel protein interactions and pathways of complex assembly. J Cell Biol 125:1327-1340.

Hirano S, Kimoto N, Shimoyama Y, Hirohashi S, and Takeichi M (1992). Identification of a neural alpha-catenin as a key regulator of cadherin function and multicellular organization. Cell 70:293-301.

Hirohashi S (1998). Inactivation of the E-cadherin-mediated cell adhesion system in human cancers. Am J Pathol 153: 333-339.

Ilyas M, Tomlinson IP, Rowan A, Pignatelli M, and Bodmer WF (1997). Beta-catenin mutations in cell lines established from human colorectal cancers. Proc Natl Acad Sci USA 94:10330-10334.

Jass JR and Sobin LH (1989). In collaboration with pathologists in nine countries. Histological typing of intestinal tumours, 2nd ed. New York: Springer-Verlag.

Kadowaki T, Shiozaki H, Inoue M, Tamura S, Oka H, Doki Y, lihara K, Matsui S, Iwazawa T, and Nagafuchi A (1994). E-cadherin and alpha-catenin expression in human esophageal cancer. Cancer Res 54:291-296.

Knudsen KA, Soler AP, Johnson KR, and Wheelock MJ (1995). Interaction of alpha-actinin with the cadherin/catenin cell-cell adhesion complex via alpha-catenin. J Cell Biol 130:67-77.

Morton RA, Ewing CM, Nagafuchi A, Tsukita S, and Isaacs WB (1993). Reduction of E-cadherin levels and deletion of the alpha-catenin gene in human prostate cancer cells. Cancer Res 53:3585-3590.

Nagafuchi A, Ishihara S, and Tsukita S (1994). The roles of catenins in the cadherin-mediated cell adhesion: Functional analysis of E-cadherin-alpha catenin fusion molecules. J Cell Biol 127:235-245.

Nagafuchi A and Takeichi M (1988). Cell binding function of $\mathrm{E}$-cadherin is regulated by the cytoplasmic domain. EMBO J 7:3679-3684.

Nathke IS, Hinck L, Swedlow JR, Papkoff J, and Nelson WJ (1994). Defining interactions and distributions of cadherin and catenin complexes in polarized epithelial cells. J Cell Biol 125:1341-1352.
Nieset JE, Redfield AR, Jin F, Knudsen KA, Johnson KR, and Wheelock MJ (1997). Characterization of the interactions of alpha-catenin with alpha-actinin and beta-catenin/plakoglobin. J Cell Sci 110:1013-1022.

Obama H and Ozawa M (1997). Identification of the domain of alpha-catenin involved in its association with beta-catenin and plakoglobin (gamma-catenin). J Biol Chem 272:1101711020.

Ozawa M, Ringwald M, and Kemler R (1990). Uvomorulincatenin complex formation is regulated by a specific domain in the cytoplasmic region of the cell adhesion molecule. Proc Natl Acad Sci USA 87:4246-4250.

Provost E and Rimm DL (1999). Controversies at the cytoplasmic face of the cadherin-based adhesion complex. Curr Opin Cell Biol 11:567-572.

Shimoyama Y, Nagafuchi A, Fujita S, Gotoh M, Takeichi M, Tsukita S, and Hirohashi S (1992). Cadherin dysfunction in a human cancer cell line: Possible involvement of loss of alpha-catenin expression in reduced cell-cell adhesiveness. Cancer Res 52:5770-5774.

Simcha I, Shtutman M, Salomon D, Zhurinsky J, Sadot E, Geiger B, and Ben Ze'ev A (1998). Differential nuclear translocation and transactivation potential of beta-catenin and plakoglobin. J Cell Biol 141:1433-1448.

Smith ME and Pignatelli M (1997). The molecular histology of neoplasia: The role of the cadherin/catenin complex. Histopathology 31:107-111.

Takeichi M (1990). Cadherins: A molecular family important in selective cell-cell adhesion. Annu Rev Biochem 59:237-252.

Takeichi M (1991). Cadherin cell adhesion receptors as a morphogenetic regulator. Science 251:1451-1455.

Tsukita S, Tsukita S, Nagafuchi A, and Yonemura S (1992). Molecular linkage between cadherins and actin filaments in cell-cell adherens junctiōns. Curr Opin Cell Biol 4:834-839.

Wachsstock DH, Wilkins JA, and Lin S (1987). Specific interaction of vinculin with alpha-actinin. Biochem Biophys Res Commun 146:554-560.

Watabe M, Nagafuchi A, Tsukita S, and Takeichi M (1994). Induction of polarized cell-cell association and retardation of growth by activation of the E-cadherin-catenin adhesion system in a dispersed carcinoma line. J Cell Biol 127:247256. 